\title{
QUR'ANICVERSES TRANSLATION SEEN FROM PERSPECTIVE OF THEIR SENSITIVITY
}

\author{
By: \\ Dolar Yuwono \\ Lecturer in STAIN Ponorogo \\ Doctoral Student of Linguistics Department \\ Postgraduate Program Sebelas Maret University \\ E-mail: dolar_yw@yahoo.com
}

\begin{abstract}
This paper discusses the translation quality of quranic verses from the point of view of their sensitivity. As containing many values and ways of life the problem that the people are facing is how to understand the values that exist in, between and beyond the lines of the Quran verses. The question is whether translation and interpretation can answer it. As a matter of fact, Qur'an verses have sensitivity to be responded in the form of the translated texts. The translated texts of Qur'an can be sensitive and controversial. Several translation version of quranic verses were taken as data to see the level of their sensitivity which can be seen from some aspect: that it may be contrary (1) to the state, (2) to religion (in a broad sense to the culture), (3) to decency, and (4) to private citizens. This category leads to a concomitant quartet of grounds for censorship: sedition, blasphemy, obscenity, and libel. The word "Yaddullah" in the section of "Al fath -verse-10", for example, from the perspective of the contextual content of the text, would have become dichotomical meaning or even multicotomical ones. The first one tends to use the foriegnization, while the second tends to use domestication. Those who defend the word "Yaddun" as "the hand" or "tangan" as its word equivalence want to make their translation original not going out of the context of Islamic teaching. They believe that those who have gone out of Islamic teaching include unbelievers (that reject faith) and idolaters. The translation of "yaddu" into "hand" or "tangan", according to some Muslims, contains the implication that the translator has its implied lack of respect for the original text, and because of the defeatist view of the ability of the target audience which entails.On the other hand, those who have translated that word "yaddun" into "power" or "kekuasaan" think that the translation into "hand" or "tangan" will disrupt and distort the image of God (Allah) existence. They are afraid that people think God is like human being having hands, head, legs and other part of the human body. Qur'an as a God's text which was revealed to the Prophet Muhammad via the archangel Gabriel, and intended for all times and all places needs to be perceived carefully because many of its verses are still stated in the forms of general statement. They need to be translated and interpreted in a way that makes people live peacefully, not on the other way around. The deference point of view in understanding Qur'an verses must be supposed to be something that makes perspective of Muslims wide and tolerant.
\end{abstract}

Key words: Qur' anic verses, translation, sensitivity 


\section{INTRODUCTION}

The entire religious life of the Muslim world is built around the text of the Qur'an. As a consequence of the Qur'an, the Arabic language moved far beyond the Arabian peninsula, deeply penetrating many other languages within the Muslim lands--Persian, Turkish, Urdu, Indonesian, and others. This supreme status stems from the belief that the Qur'an is the word of God, revealed to the Prophet Muhammad via the archangel Gabriel, and intended for all times and all places. The Qur'an was the starting point for all the Islamic sciences. The first sura (or section) of the Qur'an, al-Fatiha, which is an essential part of the ritual prayers, is learned and read in Arabic by Muslims in all parts of the world, and many other verses and phrases in Arabic are also incorporated into the lives of non-Arabic-speaking Muslims.

Therefore, Qur'an as the way and philosophy of life among the Muslims in the world has been translated into many languages. It contains 114 chapters 6666 verses. The controversial understanding and interpretation of the texts and its components in Al-Qur'an have been running controversially since Muhammad passed away in 632 leaving Qur'an not in the form of written texts but in the form of oral messages told to their followers called "Shahabad'. As an ideology, 'the text of Qur'an" may play an important role in resistance or aggression; however, it can not stand alone in the either historical or situational contexts. Thus, the topic under discussion comes from the radical perspective in interpreting and understanding the verses in Qur'an as the reference of the philosophical Islamic way of life. Some issues that have cornered the Islamic religion make the writer wants to know more about the sensitivity of intra and extra textual 'of the verses and its components in either Qur' an. At least, he can take few verses that can be examples in this discussion.

\section{QUR'ANIC VERSES AS SOCIO-SEMIOTIC PROBLEM}

As is known that denotation and connotation are two distinctive techniques to reach the meaning and sense of the text. And the text can be either sensitive or insensitive. The nature of sensitivity of the text is not because of making right or wrong decision in interpreting and translating the text, but because of the thinking of human being that makes it so. No text is sensitive (Karl Simms, 1997: 3). However, "thinking" is a human' intrinsic experience which is very influential to language. It means that each text tends to have its potential sensitivity. Whether or not this potential is realized depends on historical or cultural contingency- again, it is variable dependent on the broad context in which language is situated, rather than on the referential function of language per se (Karl Simms, 1997: 3). It means that the sensitivity of the text is based on the perspective and paradigm of thought 
where its readers are situated and educated. The sensitivity of the text is caused by two aspects: (1) depending on the references that the content of the text makes and the fact of the existence of the text itself that is placed in such away that makes it taboo. The word "Yaddullah" in the section of "Al fath -verse-10", for example, from the perspective of the contextual content of the text, would have become dichotomical meaning or even multicotomical ones.

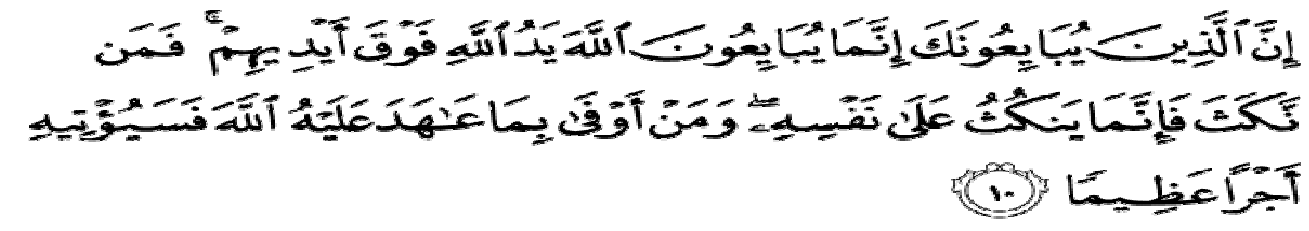

\section{Sahih International}

Indeed, those who pledge allegiance to you, [O Muhammad] - they are actually pledging allegiance to Allah. The hand of Allah is over their hands. So he who breaks his word only breaks it to the detriment of himself. And he who fulfills that which he has promised Allah - He will give him a great reward.Sahih International (Yusuf Ali's Translation)

Indeed, those who pledge allegiance to you, [O Muhammad] - they are actually pledging allegiance to Allah. The power of Allah is over their powers. So he who breaks his word only breaks it to the detriment of himself. And he who fulfills that which he has promised Allah - He will give him a great reward.

This metaphorical phrase comes from two words "yaddun" and "Allah". This word is conterminal where sensitivity is concerned. Although the phrase of the text is innocuous enough, it may arise the different concept and image of the existence of God (Allah). A group of Muslims has translated this verse into "the hand of Allah". The other group of Muslims Rendehas rejected this translation. The reason is that if Allah has a hand, he resembles his creature (human being). And it is opposite to the section "Asy-Syura-verse (11)" that "there is nothing whatever like unto Him".
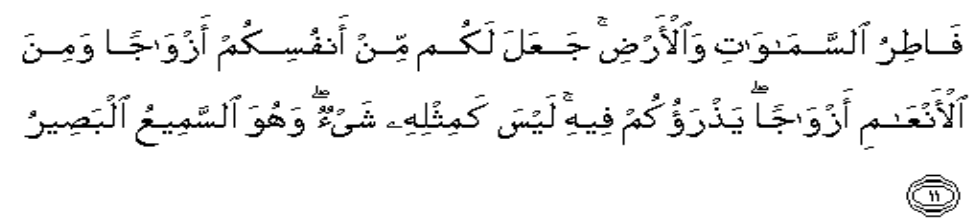

Sahih International

[He is] Creator of the heavens and the earth. He has made for you from yourselves, mates, and among the cattle, mates; He multiplies you thereby. There is nothing like unto Him, and He is the Hearing, the Seeing. 
The first and the second translation have their own reasons because each has it own ideology of their translation. The first one tends to use the foriegnization, while the second tends to use domestication. Those who defend the word "Yaddun" as "the hand" or "tangan" as its word equivalence want to make their translation original not going out of the context of Islamic teaching. They believe that those who have gone out of Islamic teaching include unbelievers (that reject faith) and idolaters. It means that the translation must be based on the opinion of the author rather than its reader. And the author of Qur'an verses is God (Allah). The translator can not change the "yaddu" with other choice of word. He/she must obey the formal equivalence of the source text (ST). Rendering each individual word of the ST into an equivalence drawn from lexicon of the target text (TT) is the only way the translator can do. Consequently, he/she must use lateral or word- for word translation technique using denotation meaning, which, accordingly is far from being idolaters.

On the other hand, those who have translated that word "yaddun" into "power" or "kekuasaan" think that the translation into "hand" or "tangan" will disrupt and distort the image of God (Allah) existence. They are afraid that people think God is like human being having hands, head, legs and other part of the human body. Therefore, in translating, the translators have their right to convey the meaning of the message in the ST into the TT with what has been hidden between and beyond the line of the ST. They are free to choose any word that is still relevant to the ST and as long as underlying message remains intact. This act of translating tends to have free translation which is on the side of the reader rather than the author (Simms: 7) and the intention of free translation is its message rather that its medium.

However, in the case of translating, descriptive translation studies (DTS) suggest that what we are looking for in translation strudies is not scientific principles or a scientific method, but rather, as Kruger has suggested, "norms" of translation (Glenn J. Err (2011: 7).

In such a translation, the image of sensitivity depends on the three perspectives. Firstly, there is the context where the sentence is situated (Simms, 1997: 3). In academic forum of discussion, for example, the word "yaddun" which is translated into "hand" is innocuous enough. Probably, they have been familiar with such kind of controversy. Secondly, there is the context of the receptors. It means that sensitivity has a broader sense related to the socio-culture of the receptors. Those who have grown up the cage of fanaticism will focus the ideal translation on what have been framed by their ancestors. And this fact has influenced the way of thinking in which the word equivalence was understood and applied 
(Glenn J. Kerr, 2011: 1). The third is that a successive, question of contexts which can be brought into play, and that is "the example" (Karl Simms: 4).

Derrida (1982: 320) points out that any linguistic entity whatever can be recontextualised as an example. Here the sensitivity becomes more sensitive (Karl Simms: 4). Is the translation of the verse "the hand of Allah" sensitive when quoted as an example of a possibly offensive verse, in academic book on study of Islam, say? The answer is not “depending on who's reading. Because it does not answer the problem of the relation between individual reader (whom I do not wish to offend) and a community readers (to whom it is amusing to be gauche) (Karl Simms: 4). As it is known that a person does not belong to one community, but rather live through networking of communities. This means that the word sensitivity is still in question. It is never clear cut thing: one can never say that is (is not) "objectively" sensitive, but neither can we say that sensitivity purely a matter of what individuals "subjectivity" perceive to be sensitive, and to claim this does not necessarily entail a deterministic view of receptor response (Karl Simms :4).

As it is still beyond the line, the nature of sensitivity in a broad sense may change from time to time and even from place to place. Although what has been written by Salman Rusdie in his Satanic Verses, for instance, has got many reactions for many years from the perspective of Muslim in Iran and other part of Muslim world, it was a political reason why Iran gave a threat of death punishment to him. This novel was considered to be hurting the Muslims' belief. Muslims think that he has humiliated prophet "Muhammad" PBUH (peace be upon to him) as the example of human being in doing good deeds in Islam.

It seems that the sensitivity of the text is also influenced by many aspects. Simms categorized it into four: that it may be contrary (1) to the state, (2) to religion (in a broad sense to the culture) (3) to decency and (4) to private citizens. This category, according to Foots (1994: 63), leads to a concomitant quartet of grounds for censorship: sedition, blasphemy, obscenity, and libel. So with this categorization, additional quotation (Isnad in arabic term.) in translating and interpreting Qur'an has its own problem to be considered. There is a common factor in these three for the first time in modern history attempted to relate, to some extent, the Qur'ânic message to the actual situation of the Muslim umma in the contemporary world, and here, for the first time for centuries, tafsîr is no longer restricted to purely academic exercise and intellectual stimulus, but regains social and political significance (Ahmad von Denffor, 2012: 3). 


\section{MODES OF QUR'AN VERSES SENSITIVITY}

Sensitivity of the text and sensitivity of translation are becoming two aspects in two sides of a coin. They can not be separated each other. It is due to many aspects that must be considered before acting of translating. One of the aspects that is very important is the modes. Freud (1973: 112) said that the translator's "interpretation" is like psychoanalyst's "interpretation". The translation of "yaddu" into "hand" or "tangan", according to some Muslims, contains the implication that the translator has its implied lack of respect for the original text, and because of the defeatist view of the ability of the target audience which entails.

Meanwhile, the terms of translating and interpreting of Qur' an are called 'tafsir" and "ta'wil". The word tafsîr is derived from the root 'fassara' - to explain, to expound. It means 'explanation' or 'interpretation'. In technical language the word tafsîr is used for explanation, interpretation and commentary on the Qur'ân, comprising all ways of obtaining knowledge, which contributes to the proper understanding of it, explains its meanings and clarifies its legal implications. The word mufassir (pl. mufassirûn) is the term used for the person doing the tafsîr, i.e. the 'exegete' or 'commentator'. The word ta'wîl, which is also used in this connection, is derived from the root 'awwala' and also means 'explanation, interpretation'. In technical language it similarly refers to explanation and interpretation of the Qur'ân.

Tafsîr in the language of the scholars means explanation and clarification. It aims at knowledge and understanding concerning the book of Allah, to explain its meanings, extract its legal rulings and grasp its underlying reasons. Tafsîr explains the 'outer/surface' (zahir) meanings of the Qur'ân. Ta'will is considered by some to mean the explanation of the inner (deep) and concealed meanings of the Qur'ân, as far as a knowledgeable person can have access to them. Others are of the opinion that there is no difference between tafsîr and

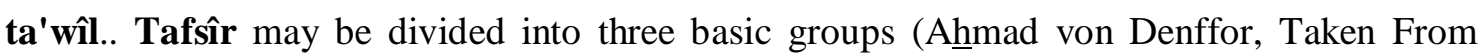
Ibrahîm Shafi' Islamworld, Jounal Islam, 2012, Volume LV, Part 3.):

- Tafsîr bi-l-riwâya (by transmission), also known as tafsîr bi-l-ma'thûr.

- Tafsîr bi'l-ra'y (by sound opinion; also known as tafsîr bi-l-dirâya, by knowledge).

- Tafsîr bi-l-ishâra (by indication, from signs).

Related to the above concept of translating and interpreting Qur'an, perhaps one way of managing them is through negotiation by using intertexuality concepts. Intertextuality is a concept developed from French structuralism in the 1960's and seen as a new way of 
articulating the effects of what used to be called "influence" (Basil Hatim in Simms: 10). It means that the translation will not be tied with chronological direction, but with what the texts have in common with other texts which proceed and succeed them (Isnad or sanad in Tarsir term). It was conceived at the level of "semes", but more recent empirical work by Michael Hoey (1991 - 1997), and others has explored intertextuality effects at both discursive and lexical level, as wel as allowing back speculation regarding the linguistic psychology of text procedures, although intertextual borrowing are still held to be unconscious (Riffatarre 1988 in Simm: 11) or subconscious (Hoey, 1994). Thus, intertextuality, based on the realms theory of translation is positing an ideal intertext or referential "pool" which the translator draw appropriate lexis, style, and phraseology (Hatim in Simm: 11). Therefore, intertext becomes a sub-set which is specifically linguistic, and which is quasi-objective, being equally accessible to any (good, or at least competent) translator, and less equally on the translator's personal experience.

On one hand, over the years, a large body of commentaries on the Quran has accumulated, and differences in interpretation can be observed both between the various traditions within Islam (such as Sunni, Shii, or Sufi) (Netton (1992) in Haleem, 2001) and between different periods in history. It is not the intention here to go into detail, but some illustrative examples may give the reader some understanding of the complexity and sophistication of views that arise from reading the Quran.

An important feature of the Quranic style is that it alludes to events without giving their historical background. Those who heard the Quran at the time of its revelation were fully aware of the circumstances. Later generations of Muslims had to rely on the body of literature explaining the circumstances of the revelations (asbab al-nuzul), (found in the Quran) and on explanations and commentaries based on the written and oral records of statements by eyewitnesses. These oral testimonies were collected and later written down.

Some examples will illustrate this feature of sensitivity, for instance the verse 'Slay them wherever you find them' (2: 191), (Dawood, 1990) thus translated by Dawood and taken out of context, has been interpreted to mean that Muslims may kill non-Muslims wherever they find them. In factm, the only situations where the Quran allows Muslims to fight are in self-defense and to defend the oppressed who call for help (4: 75), but even in the latter case this is restricted to those with whom the Muslims do not have treaty obligations (8: 72). The pronoun 'them' here refers to the words 'those who attack you' at the beginning of the previous verse. Thus the Prophet and his followers are here being allowed to 
fight the Meccans who attack them. The Quran makes many general statements but it is abundantly clear from the grammar and the context of this statement that this is not one of them. 'Wherever you find them' or 'come up against them' is similarly misunderstood. As exegetes and commentators explain, the Muslims were anxious that if their enemies attacked them in Mecca, which was and is a sanctuary (in which no Muslim is allowed to fight, or kill even an animal or plant), and they retaliated and killed, they would be breaking the law. The Quran simply reassured the Muslims that they could defend themselves when attacked, even if they killed their attackers, whether within the sanctuary or outside it. However, the six verses that concern war (2: 190-5) contain many restrictions and are couched in restraining language that appeals strongly to the Muslims' conscience. In six verses it is found four prohibitions; seven restrictions (one 'until', four 'if ', two 'who fight you'); as well as such cautions as 'in God's cause', 'be mindful of God', 'God does not love those who overstep the limits', 'He is with those who are mindful of Him', loves 'those who do good', and 'God is most forgiving and merciful'. The prevalent message of the Quran is one of peace and tolerance (Haleem, 2001: 187 - 208) but it allows self-defense.

Equally misinterpreted and taken out of context is what has become labeled as the sword verse' (9: 5) although the word 'sword' does not appear in the Quran: 'When the [four] forbidden months are over, wherever you find the polytheists, kill them, seize them, besiege them, ambush them'. The hostility and 'bitter enmity' of the polytheists and their fitna (tumult or oppression) (persecution: 2: 193; 8: 39) of the Muslims during the time of the Prophet became so great that the disbelievers were determined to convert the Muslims back to paganism or finish them off: 'They will not you revoke your faith, if they can' (2: 217). It was these hardened polytheists in Arabia, who would accept nothing other than the expulsion of the Muslims or their reversion to paganism, and who repeatedly broke their treaties, that the Muslims were ordered to treat in the same way, either to expel them or to accept nothing from them except Islam. But, even then, the Prophet and the Muslims were not simply to pounce on such enemies, reciprocating by breaking the treaty themselves: an ultimatum was issued, giving the enemy notice that, after the four sacred months mentioned in 9: 5 above, the Muslims would wage war on them.

Yet the main clause of the sentence 'kill the polytheists' is singled out by some nonMuslims as representing the Islamic attitude to war; even some Muslims take this view and allege that this verse abrogated many other verses, including 'There is no compulsion in religion' (2: 256) and even, according to one solitary extremist, 'God is forgiving and 
merciful'. This far-fetched interpretation isolates and decontextualizes a small part of a sentence and of a passage, 9: 1 - 15, which gives many reasons for the order to fight such polytheists: they continually broke their agreements and aided others against the Muslims, they started hostilities against the Muslims, barred others from becoming Muslims, expelled them from the Holy Mosque and even from their own homes (It happened in Indonesia in treating other group of Muslim who have different perspective in understanding Qur' an and Hadith, even killed them). At least eight times the passage mentions the misdeeds of these people against the Muslims. Moreover, consistent with restrictions on war elsewhere in the Quran, the immediate context of this 'sword verse' exempts such polytheists as do not break their agreements and who keep the peace with the Muslims (9: 7); it orders that those enemies seeking safe conduct should be protected and delivered to the place of safety they seek (9: 6). The whole of this context to verse 5, with all its restrictions, is ignored by those who simply isolate one part of a sentence to build on their theory of war and violence in Islam.

One further cause for misinterpretation is the lack of awareness of the different meanings of a given term in different contexts (see below), 'This Translation: Identifying Aspects of Meaning'). Thus, for example, in Dawood's translation: 'He that chooses a religion other than Islam, it will not be accepted of him and in the world to come, he will be one of the lost' (3: 85), (Dawood, 1990) it has to be borne in mind that the word islam in the Arabic of the Quran means complete devotion/submission to God, unmixed with worship of any other. All earlier prophets are thus described by the Quran as muslim. Those who read this word Islam in the sense of the religion of the Prophet Muhammad will set up a barrier, illegitimately based on this verse, between Islam and other monotheistic religions. The Quran clearly defines its relationship with earlier scriptures by saying: 'He has sent the Scripture down to you [Prophet] with the Truth, confirming what went before: He sent down the Torah and the Gospel earlier as a guide for people' (3: 3 - 4). Indeed it urges the Christians and the Jews to practice their religion $(5: 68,45,47)$. They are given the honorific title of 'People of the Book', and the Quran appeals to what is common between them: 'Say, 'People of the Book, let us arrive at a statement that is common to us all: we worship God alone, we ascribe no partner to Him, and none of us takes others beside God as lords"' (3: 64). The Quran forbids arguing with the People of the Book except in the best way and urges the Muslims to say: 'We believe in what was revealed to us and in what was revealed to you; our God and your God are one [and the same]' (29: 46). God 
addresses Muslims, Jews, and Christians with the following: 'We have assigned a law and a path to each of you. If God had so willed, He would have made you one community, but He wanted to test you through that which He has given you, so race to do good: you will all return to God and He will make clear to you the matters you differed about' (5: 48). The Quran allows Muslims to eat the food of the People of the Book and marry their women (5: 5). These are explicit statements which Muslims involved in interfaith dialogue rely upon.

Misinterpretation is also observed with regard to the status of women. For example, 2: 228 'husbands have a degree [of right] over them [their wives]' has been variously interpreted by Muslims and non-Muslims to relegate women in general to a lower status, when in fact this cannot be based on this verse. The reference here is not to 'women' and 'men' but to 'wives' and 'husbands'. The context is in questions of divorce, between wives and husbands. Partly based on a misinterpretation of this verse, for example, most traditional scholars came to the view that Muslim women could not be judges, whereas Abu Hanifa (d. ah 150/767 ce), the founder of one of the four main schools of Islamic law, and modern jurists in many Muslim countries (although not all) do also allow women to be judges. A further example of discrimination against women due to disregard of context is found in the way some scholars interpreted 2: 282. In urging the recording of a debt in writing, the Quran says: 'Call in two men as witnesses. If two men are not there, then call one man and two women out of those you approve as witnesses, so that if one of the two women should forget the other can remind her.' The majority view was to generalize this to all testimony.

\section{CONCLUSION}

In the context of translating, the question that arises is that translation is an art or science. What so ever definition a translator perceive, he or she must remember that a scientific method in translating is a repeatable procedure with the same result in each time. Qur'an as a God's text which was revealed to the Prophet Muhammad via the archangel Gabriel, and intended for all times and all places needs to be perceived carefully because many of its verses are still stated in the forms of general statement. They need to be translated and interpreted in a way that makes people live peacefully, not on the other way around.

The deference point of view in understanding Qur'an verses must be supposed to be something that makes perspective of Muslims wide and tolerant as it is mentioned in the section 42 verse 14 "And they became divided only after knowledge reached them, through selfish envy as between themselves .." and verse 16 'But those who dispute 
concerning Allah after he has been accepted, futile is their dispute in the sight of their lord: on them is Wrath, and for them will be Penalty terrible".

The writer closes this article with two suggestions: first to seek the deep understanding in translating Qur'an based on the wide perspective of Translation, and thereby incorporating ideas secular researcher (ulama and experts in qur'an), and second to undertake the suitable approach to translation in which the form of TT (for example, such as it is metaphoric, idiomatic, gender inclusive or gender specific) is determined by the need of the target audience.

\section{REFERENCES}

Abdel M. A. S. Haleem. 1992. "Grammatical Shift for the Rhetorical Purposes: Iltifăt and Related Features in the Qur'ān”. Bulletin of the School of Oriental and African Studies, Journal Islam, 1992, Volume LV, Part 3.

Abdel Haleem, M. 2001. Understanding the Quran: Themes and Style. London: I. B. Tauris.

Abubakar, B. 2005. Terjemah Tafsir Jalalain Berikut Asbabun Nuzul Jilid 1. Bandung: PT Sinar Baru Algesindo.

Abu Zaid, Nasr Hamid. 1987. Tekstualitas Alquran: Kritik terhadap Ulumul Quran, (Terjemahan oleh Khoiron Nahdliyyin. 2001. Yogyakarta: LkiS).

Abdullah Yusuf Ali. 1991. The Meaning of Holly Qur'an: Arabic to English. Brentwood, Maryland: Amana Cooperation.

Ahmad von Denffor. Tafsîr, Its Kinds \& Principles: Interpreting the Text. From The Book 'Ulum al-Qur'ân (@), Taken from Ibrahîm Shafi' Islamworld) (c) Islamic Awareness, All Rights Reserved. Journal Islam, 2012, Volume LV, Part 3.

Andy Cheung. 2013. "A History of Twentieth Century Translation Theory and Its Application for Bible Translation”. Journal of Translation Volume 9, Number 1.

Dawood, N. J.'s translation. (1990). The Koran. Harmondsworth: Penguin Classics.

Derrida, Jacques. 1982. Signiture Event Context, in: Margin of Philosophy, tran. Alan Bass. Brighton: Harvester.

Glenn J. Kerr. 2011. "Dynamic Equivalence and Its Daughters: Placing Bible Translation Theory in Their Historical Context". Journal of Translation Volume 7, Number 1. 
Simms, Karl. 1997. Translating Sensitive Text: Linguistic Aspects. Edition Rudopi B. V. Amsterdam-Atlanta GA The Netherlands.

Yayasan Penyelenggara Penerjemah Al-qur'an. Al-Qur'an Tiga Bahasa: Arabic, Indonesian, and English. Jakarta: Al-Huda. 